\title{
Evaluation of Students' Views on the Covid-19 Distance Education Process in Music Departments of Fine Arts Faculties
}
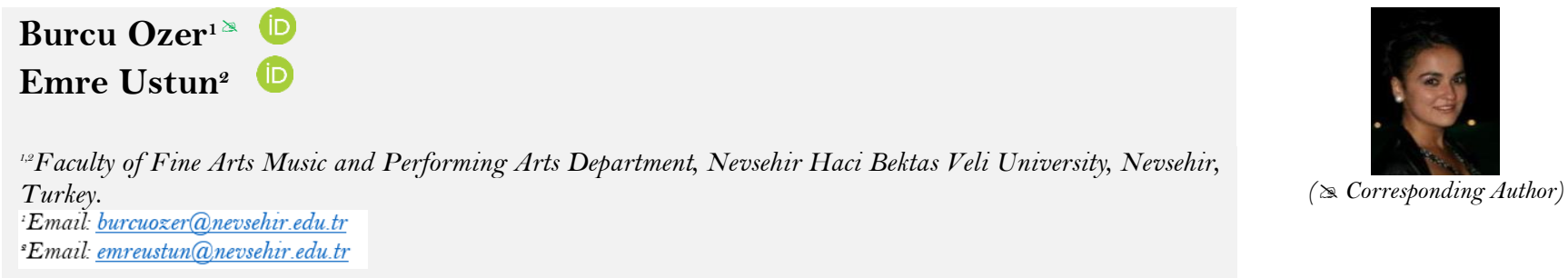

Email:emreustun@nevsehir.edu.t

\section{Abstract}

The purpose of this study is to determine evaluations and recommendations of the students, who took distance education in the spring semester of 2019-2020 in the music departments of fine arts, about this education and training process, and to develop suggestions for solving the problems experienced. In line with this purpose, the research universe is composed of music departments of fine arts faculties of universities in Turkey, and the sample consists of 1st, 2nd, 3rd and 4th grade students studying in Music and Performing Arts at Nevsehir Hacı Bektas Veli University, Faculty of Fine Arts. In order to evaluate music department courses with distance education in terms of learning-teaching process, 24 students were interviewed using a semi-structured observation form consisting of 14 questions for students of music department. In the data collection and analysis of the research, the obtained data were evaluated by using descriptive content analysis technique. In line with the findings obtained from the interviews with the students of the music department, it was concluded that web-based distance education is not as efficient as face-to-face education especially in applied courses, the connection and technical problems experienced during the courses negatively affect the education process, there should be attendance requirement in distance education courses and students with limited opportunities should be provided necessary technological support, and the students want to continue their education as face-to-face in the post-pandemic period.

Keywords: Covid-19, Distance education, Fine arts, Music education, Applied course, Performing arts.

Citation | Burcu Ozer; Emre Ustun (2020). Evaluation of Students" Views on the Covid-19 Distance Education Process in Music Departments of Fine Arts Faculties. Asian Journal of Education and Training, 6(3): 556-568.

\section{History:}

Received: 11 August 2020

Revised: 21 August 2020

Accepted: 28 August 2020

Published: 7 September 2020

Licensed: This work is licensed under a Creative Commons

Attribution 3.0 License (c) E E

Publisher: Asian Online Journal Publishing Group
Acknowledgement: Both authors contributed to the conception and design of the study.

Funding: This study received no specific financial support.

Competing Interests: The authors declare that they have no conflict of interests.

Transparency: The authors confirm that the manuscript is an honest, accurate, and transparent account of the study was reported; that no vital features of the study have been omitted; and that any discrepancies from the study as planned have been explained.

Ethical: This study follows all ethical practices during writing.

\section{Contents}

1. Introduction

3. Data Collection

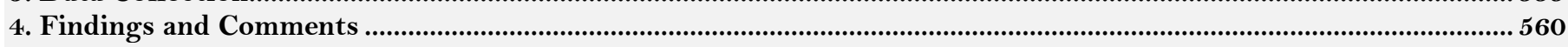

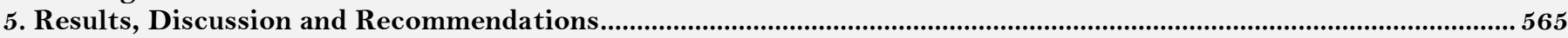

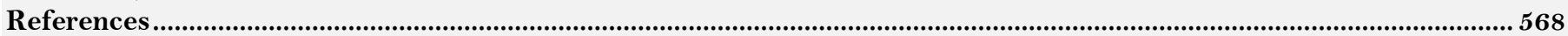




\section{Contribution of this paper to the literature}

This study contributes to the literature by evaluating this education process of the students who receive distance education in the departments of music in the spring semester of 2019-2020, determining their suggestions and developing suggestions for solving the problems experienced.

\section{Introduction}

With the Covid-19 pandemic that broke out in Wuhan, China at the end of 2019, a more isolated way of life was adopted in order to be protected from disease by changing the usual lifestyles around the world. In order to be protected from the transmission risk of the disease by providing this isolation in education, as in all areas of life, face-to-face education and training activities were stopped at all levels of education and started to be carried out in the form of distance education in the spring semester of 2019-2020, in our country, as well as in many countries.

Despite all the measures taken, the epidemic has spread all over the world. States have made it mandatory to take measures due to the rapidly increasing number of cases and deaths worldwide (Wang, Zhang, \& Du, 2020). As a result of the restrictions on freedom of movement, changes in daily life and education have also become important. UNESCO (2020) reported that "1.5 billion children and young people were affected by school closure in 195 countries since mid-April." (Daubney \& Fautley, 2020).

According to his study, Zhong (2020) explained that 770 million people were affected by the pause of education worldwide. As a result of the measures taken, education has been suspended in almost all countries, and then each country has tried to proceed by determining its own method on how education should continue.

Universities in Turkey are subject to Higher Education Council (YÖK). YÖK first announced that universities were on holiday for 3 weeks on March 16, 2020. Later, it instructed universities to give courses through distance education and stated that formal education cannot be held in the spring semester of 2019-2020 academic years. According to the decisions taken by YÖK, universities had to start distance education as of 23 March 2020 in terms of their capacities. There are 123 distance education units in universities of Turkey. Especially universities with Distance Education Unit have been enabled to plan and implement educational activities by using their own infrastructure (YOK, 2020a).

In line with these decisions of YÖK, many universities completed their studies within a week and on 23 March 2020, courses started to be taught by distance education method. Universities used synchronous, "asynchronous" or "both synchronous and asynchronous" distance education methods as much as their infrastructure allowed.

Distance education and online learning are not new concepts. Everywhere and every place with the internet access have an advantage in terms of distance education. With this method, the student can be trained wherever $\mathrm{s}$ /he wants, regardless of the school and classroom environment where $\mathrm{s} /$ he is trained in traditional face-to-face education.

Distance learning is a modern and effective form of learning that can be offered regardless of location and time, and has features such as the ability to configure educational materials electronically and flexibly, to update and add different technologies to the learning process, and to be available 24/7 (Altun, Telli, \& Yamamoto, 2020).

Web-based distance education in Turkey is implemented as a method carried out by means of Distance Education Application and Research Centers (UZEM) of Anadolu University, Istanbul University, Ataturk University, and some other universities. However, in the Covid-19 pandemic process, all universities switched to a web-based distance education process with a rapid crisis management in order to keep the education-training process intact.

Every educator and learner, with or without experience in distance education, had to give or take courses via distance education in no time at all. Educational institutions and educators searched for how the courses can be done with distance education and how to use various online tools (Karip, 2020).

The compulsory distance education process, which started with a pandemic process in all areas of education, started to be implemented in the music departments of the fine arts faculties. Until the recent changes brought about by the Covid-19 outbreak, music department undergraduate education in fine arts faculties was traditionally structured as face-to-face learning. The 4-year undergraduate program has a structure in which applied courses are dominant, and theoretical courses are supported by applied courses.

According to the "Press Release" made by YÖK on March 26, 2020, theoretical parts of some applied courses of universities along with theoretical courses could be carried out via distance education and compensatory training could be held in the summer months (YOK, 2020a). However, due to the uncertainty of the process, whether education would continue in the summer period could not be clarified. For this reason, applied courses were carried out in the form of distance education according to departments by the decision made within the universities. In this process, in the music departments of fine arts faculties, applied courses together with theoretical ones were given by distance education method. This situation brought along some advantages and disadvantages.

In order for this process to be structured correctly, students' sources of access to information, how they changed during this process, and what students, who have spent this period of higher education through distance education, experienced in this process should be known (Keskin \& Ozer, 2020).

As a result of the literature review, it was seen that some studies have been carried out within the scope of distance education in music education.

Adileh (2012) in his article titled "Teaching music as a university elective course through e-learning", compared the attitudes and course achievements of 179 university students who took elective music courses at AlQuads university, and applied a mixed education model where face-to-face and online education for the experimental group and only face-to-face education model for the control group are used. As a result of the evaluations, it was seen that the results of the group in which the mixed education model was applied were found to be much more successful than the group in which the face-to-face education model was applied.

Karahan (2016) in his experimental study where he aimed to determine the success levels of distance piano courses according to the success levels of students in traditional piano courses, concluded that simultaneous distance piano courses improve students' piano playing performances at a level close to traditional piano courses. 
In his doctoral thesis titled "The Effect of Distance Learning Model on Violin Learning", Okan (2017) conducted violin courses for eight weeks in the form of face-to-face education with the control group and in the form of distance education with the experimental group; as a result, he determined that there is no differentiation between the experimental and control groups in beginner and middle levels.

Yungul (2018) in his PhD thesis titled "Applicability of Web-Based Distance Education in Instrument (Guitar) Education", conducted a web-based experimental study within the scope of synchronous and asynchronous model for guitar education in Fine Arts High Schools and as a result of this study, he concluded that there was no significant difference between the last test scores of students who had web-based distance learning, and who had training with traditional education method, but distance education method was more effective on student performances and that this method was "practical", "useful" and "effective in the processing of the curriculum" as a result of interviews with students studying with distance education method.

However, these studies cover certain courses and a non-compulsory process. Determination of the gains, problems, and suggestions, obtained in the departments of compulsory distance education during the pandemic period in the music departments according to the opinions of the students, are considered to be important for reorganizing this process in terms of the teaching of the music department in the future education periods and to set an example for other researches to be carried out.

This study aims for students to evaluate education process in music departments of fine arts, in the spring term of 2019-2020, to determine their recommendations and to develop suggestions for solving the problems experienced.

For this purpose, the evaluations of the students studying in the music departments of fine arts faculties for the distance education period applied in the Covid-19 process constitute the problem of the research.

Sub-problems arising from the interview form applied to students in the research are as follows:

1. What are the problems that the students of the music department of the faculty of fine arts faced during the Covid-19 distance education process?

2. What are the findings of the students of the music department of the faculty of fine arts regarding the Covid-19 distance education process?

3. What are the evaluations of students of the music department of the faculty of fine arts regarding the Covid-19 distance education process?

4. What are the recommendations of the students of the music department of the faculty of fine arts regarding the Covid-19 distance education process?

\section{Methodology}

In this part of the research, the measures taken in order to reach the purpose of the research and to obtain valid and reliable results are explained in detail, and the research model, the universe and the sample of the research, data collection, data analysis and interpretation are discussed.

\subsection{Semi-Structured Interview Method}

In this technique, the researcher prepares the interview protocol containing the questions that s/he plans to ask in advance. Depending on the flow of the interview, the researcher has the person detail her/his responses. If some questions are answered within the other questions during the interview process, these may not be asked. Using flexibility in this interview technique makes it a more suitable technic for educational research. Therefore, it can be seen within qualitative research (Turnuklu, 2000). This interview technique is a more suitable form of research for educational sciences studies in terms of providing more systematic and comparable information by continuing with the previously prepared interview protocol (Esen, Oral, \& Yalcinkaya, 2014).

\subsection{Research Model}

This research is a descriptive study in terms of the method followed and the quality of the data collected. "Descriptive analysis: according to this approach, the data obtained are summarized and interpreted according to the previously determined themes. The data summarized and interpreted in descriptive analysis are subjected to a deeper process in content analysis, and concepts and themes that cannot be detected by a descriptive approach can be discovered as a result of this analysis" (Yildirim \& Simsek, 2006). The data can be arranged according to the themes put forward by the research questions, or can be presented by considering the questions or dimensions used in the interview and observation processes. In the descriptive analysis, direct quotations are often included to reflect the views of the individuals interviewed or observed. In this type of analysis, the aim is to present the findings to the reader in an organized and interpreted way." (Yildirim \& Simsek, 2006). Also, in this study, one of the qualitative research methods, easy accessibility sampling method was used. In general terms, the research is planned as a case study. The situation is similar to the case studies in quantitative researches. The situation can be an individual, event, phenomenon or an institution. In case studies, the aim is to examine a particular situation in depth and reach comprehensive results. The most prominent feature of case studies is that due to the fact that each situation is different from other cases, there is no generalizability. However, data in one case study can be used for another study (Kose, 2013). In the research, semi-structured interview form was used as data collection tool. In this method, "the researcher prepares the interview questions in advance; however, it allows the reorganization and discussion of the questions created by providing flexibility to the researched people during the interview. In such a meeting, the researched people also have control over the research." (Ekiz, 2003). Semi-structured interview method was used to determine the observations of undergraduate $1^{\text {st }}, 2^{\text {nd }}, 3^{\text {rd }}$ and $4^{\text {th }}$ grade students in music departments of fine arts faculties about distance education applied in the Covid-19 process. Interviews were made online and an average of 20-30 minutes was allocated for each interview. The recorded interviews were converted into written texts in the electronic environment. For the answers given to each question in the determined interview results, the general common opinions of the students were examined by 2 experts. At the last stage, the data are expressed as a structured summary. 


\subsection{Study Group}

The universe of this research is composed of fine arts education departments of universities in Turkey, and the sample consists of $1^{\text {st }}, 2^{\text {nd }}, 3^{\text {rd }}$ and $4^{\text {th }}$ grade students studying in Music and Performing Arts at Nevsehir Hacl Bektas Veli University, Faculty of Fine Arts.

Table-1. Distribution of students' according to grade levels.

\begin{tabular}{l|c|c}
\hline Class Level & $\mathbf{N}$ & $\mathbf{\%}$ \\
\hline $1^{\text {st }}$ grade & 6 & 25 \\
\hline $2^{\text {nd }}$ grade & 6 & 25 \\
\hline $3^{\text {rd }}$ grade & 6 & 25 \\
\hline $4^{\text {th }}$ grade & 6 & 25 \\
\hline Total & 24 & 100 \\
\hline
\end{tabular}

When Table 1 is examined, it is seen that the students determined for the application of the interview form are selected from each grade equally and constitute $25 \%$ of the total for each grade.

Table-2. Distribution of students' according to grade point averages.

\begin{tabular}{c|c|c|c}
\hline Class Level & N & GPA & Success Average \\
\hline $1^{\text {st }}$ grade & 6 & 3,21 & $\% 80$ \\
\hline $2^{\text {nd }}$ grade & 6 & 3,13 & $\% 78$ \\
\hline $3^{\text {rd }}$ grade & 6 & 3,50 & $\% 87$ \\
\hline $4^{\text {th }}$ grade & 6 & 3,47 & $\% 86$ \\
\hline Total & 24 & 4,00 & $\% 100$ \\
\hline
\end{tabular}

When Table 2 is analyzed, it can be seen that the general success averages of the students determined for the application of the interview form are $80 \%$ for the $1^{\text {st }}$ grades, $78 \%$ for the $2^{\text {nd }}$ grades, $87 \%$ for the $3^{\text {rd }}$ grades and $86 \%$ for the $4^{\text {th }}$ grades.

Table-3. Distribution of students' according to individual instruments.

\begin{tabular}{c|c|c}
\hline Individual Instrument & $\mathbf{N}$ & $\mathbf{\%}$ \\
\hline Bağlama & 7 & 29,16 \\
\hline Violoncello & 4 & 16,66 \\
\hline Flute & 3 & 12,50 \\
\hline Clarinet & 3 & 8,50 \\
\hline Oud & 2 & 4,16 \\
\hline Guitar & 1 & 4,16 \\
\hline Violin & 1 & 4,16 \\
\hline Piano & 1 & 4,16 \\
\hline (Vocal training) & 1 & 4,16 \\
\hline Viola & 1 & 100 \\
\hline Total & 24 & \\
\hline
\end{tabular}

In Table 3 when the individual instrument status of the students participating in our study is examined, it is seen that $29 \%$ of them took courses on baglama, $16 \%$ on violoncello, $12 \%$ on flute, $12 \%$ on clarinet, $8 \%$ on oud, $4 \%$ on guitar, $4 \%$ on violin, $\% 4$ on piano, $4 \%$ on viola and $4 \%$ on individual vocal training (singing).

\section{Data Collection}

Screening method was used in the first stage of this research. In this sense, music education and distance education method has been determined by scanning local and foreign sources in terms of basic, technical and musical behavior. In addition, a semi-structured interview form was used for the observation, thoughts and opinions of all music department students, studying in the 2019-2020 academic year, about the distance education process, and the qualitative method was used to analyze the applied interview form. In the preparation of the interview form, it was kept in sight that the questions are understandable and not guiding. In addition, the form was presented to the experts for its purpose and applicability. The content of the form, language rules and clarity of the questions were examined by the experts. Following this process, the interview form was finalized in line with the suggestions. Depending on this purpose, a question pool consisting of 24 questions was created by the researchers. This question pool was reduced to 19 questions upon receiving expert opinions from the field of educational sciences. In the pilot application (10 students), 3 more questions that could not be understood and obtain clear answers were excluded as a result of the analysis of the form. After this process, with the finalization of the form in line with the opinion of the experts, 2 more questions were left out and the semi-structured observation form consisting of 14 questions was made ready for implementation. In this sense, in order to implement the form, a total of 40 students were interviewed, as 10 students from each grade. As a result of the interviews, the data of the students who did not provide reliability during the data analysis phase or slurred over the questions with short answers and did not answer some of the questions were excluded from the analysis and the number was reduced to 30 students. After this stage, in order to get equal number of students' opinions from each grade, the opinions of 24 students whose grade point average is above 3.00 were evaluated as findings. These 24 students were gathered by selecting 6 people from each grade. After this stage, findings and comments were made as a result of the analysis of the data. 24 students of music department were asked 14 questions and the obtained data were evaluated.

\subsection{Analysis of the Data}

In the data collection and analysis of the research, the obtained data were evaluated by using descriptive content analysis technique. In the content analysis, data obtained through interviews, observations or documents 
are analyzed in four stages: (1) encoding data, (2) finding codes, categories and themes, (3) organizing codes, categories and themes, (4) defining and interpreting the findings (Miles \& Huberman, 1994). For qualitative researchers, not quantity but quality is important. Therefore, they do not have basic goals such as getting the percentage of codes and tabulating. Looking at how often the code passes in qualitative research gives the researcher information about the density and weight of that code. The categories are not raw data itself, but an abstracted form of data, and they are conceptual components that include many individual examples. Creating categories is conceptualizing the data in this context and moving it to a higher dimension. Decreasing the number of categories is a sign that a higher level of abstraction is made (Merriam, 2009; Miles. \& Huberman, 2016).

According to Buyukozturk, Cakmak, Akgun, Karadeniz, and Demirel (2010) descriptive content analysis is defined as the analysis of a text with determined codes and small content categories. The validity and reliability stages of the semi-structured interview form used in this sense can be listed as follows;

- Validity phase: The obtained data are written in detail and the results obtained are presented clearly and understandably.

- Internal validation phase: Getting the opinions of experts from the field of educational sciences at the stages of analyzing the data and interpreting the findings.

- External validity phase: Being transferable of the form prepared for the distance education process by evaluating the interview form under the same conditions for all students.

- Internal reliability phase: For the interview form to be suitable for the purpose, finalizing it in line with the opinion of the experts, and evaluating it by making a pilot application.

- External reliability stage: Keeping the information of the interview forms.

\section{Findings and Comments}

4.1. Findings and Comments on the First Sub-Problem

In the first sub-problem of the research, the answer to the question of "What are the problems that the students of the music department of the faculty of fine arts faced during the Covid-19 distance education process?" was sought. In the interview form for this problem, findings and comments regarding the data obtained from the questions of "What are the problems you encounter in applied courses during the Covid-19 distance education process?" and "What are the problems you encounter in theoretical courses during the Covid-19 distance education process?" are as follows:

\begin{tabular}{|c|c|c|c|}
\hline Grade & Themes & Category (Views) & Codes \\
\hline \multirow[t]{4}{*}{$1^{\text {st }}$ grade } & Applied courses & Negative (5) & Internet connection \\
\hline & & Positive (1) & $\begin{array}{l}\text { Study environment } \\
\text { Unproblematic process }\end{array}$ \\
\hline & $\begin{array}{c}\text { Theoretical } \\
\text { courses }\end{array}$ & Negative (2) & $\begin{array}{l}\text { Connection problem } \\
\text { Attention deficit }\end{array}$ \\
\hline & & Positive (4) & Unproblematic process \\
\hline \multirow[t]{3}{*}{$2^{\text {nd }}$ grade } & Applied courses & Negative (5) & $\begin{array}{l}\text { Internet connection } \\
\text { Study environment }\end{array}$ \\
\hline & & Positive (1) & Unproblematic process \\
\hline & $\begin{array}{l}\text { Theoretical } \\
\text { courses }\end{array}$ & $\begin{array}{l}\text { Negative (2) } \\
\text { Positive (4) }\end{array}$ & $\begin{array}{l}\text { Connection problem } \\
\text { Indifference to courses } \\
\text { Unproblematic process }\end{array}$ \\
\hline \multirow[t]{4}{*}{$3^{\text {rd }}$ grade } & Applied courses & Negative (6) & $\begin{array}{l}\text { Internet connection } \\
\text { Material deficiency } \\
\text { Problems in adapting to the system } \\
\text { Problems in self-expression }\end{array}$ \\
\hline & & Positive $(-)$ & $\begin{array}{ll}--- \\
\end{array}$ \\
\hline & $\begin{array}{l}\text { Theoretical } \\
\text { courses }\end{array}$ & Negative (4) & $\begin{array}{l}\text { Excessive homework } \\
\text { Difficulty in understanding the courses } \\
\text { Communication problems with teachers }\end{array}$ \\
\hline & & Positive (2) & Unproblematic process \\
\hline \multirow[t]{4}{*}{$4^{\text {th }}$ grade } & Applied courses & Negative (6) & $\begin{array}{l}\text { Internet connection } \\
\text { Problems in adapting to the system }\end{array}$ \\
\hline & & Positive (-) & - \\
\hline & $\begin{array}{l}\text { Theoretical } \\
\text { courses }\end{array}$ & Negative (2) & $\begin{array}{l}\text { Connection problem } \\
\text { Informational convergence }\end{array}$ \\
\hline & & Positive (4) & Unproblematic process \\
\hline
\end{tabular}

Considering Table 4, it was concluded that all four grades experienced problems related to the internet connection in applied courses. In addition, $1^{\text {st }}$ and $2^{\text {nd }}$ grades stated that they had problems in terms of working environment in applied courses and $9^{\text {rd }}$ and $4^{\text {th }}$ grades were not able to adapt to the system. Also, $3^{\text {rd }}$ grade students stated that they could not express themselves in the distance education process in the applied courses and that they had problems arising from the lack of materials. Only two students from $4^{\text {th }}$ grade stated that they did not have any problems in applied courses. In this case, it was concluded that there were problems in applied courses during the distance education process.

S.3 (1): "We had problems in most of the applied courses. For example, we could not read the songs that we will read in chorus in the collective singing course. The most important thing is the internet connection problem."

S.2 (2): "The individual instrument course as one of the applied courses, and the lack of working environment. Since everyone is at home, the instrument can be irritating for the elderly, children, etc. for example; clarinet sound for apartment residents." 
S.2 (3) "Comfort and self-expression in face-to-face education was a more positive process for me. But here the possibility of confusing some things because of the excitement of being in front of the camera is increasing as a percentage, which has turned into a problem for me."

S.6 (4) "I can say connection problems in the first place. In many live courses, the voice of my teachers was interrupted every few seconds. Sometimes voices were transmitted to the other party with a few second intervals."

In theoretical courses, the common answer given by $1^{\text {st }}, 2^{\text {nd }}$ and $4^{\text {th }}$ grade is in terms of problems experienced in the internet connection, as in applied courses. They stated that they experienced attention deficit, indifference to the course, difficulty in understanding the course and difficulties in communicating with the teachers, and that there was an informational convergence in theoretical courses. For the theoretical courses, 13 students expressed a positive opinion that the process went smoothly. According to this result, it can be concluded that theoretical courses are more efficient than applied courses in the distance education process.

S.2 (1) "I did not encounter any problems in theoretical courses."

S.3 (2) "We had problems in loading homework from time to time in theoretical courses."

S.6. (3) "When we were at school, we could ask questions to our teachers whenever we wanted, but we can only communicate on the day of the course in distance education. In addition, homework is given for the exam, but the student who is not interested in this course asks the homework from a successful student and even s/he does not understand this course s/he is considered as successful."

S.4 (4) "I think there is an informational convergence, and course contents are too much."

\subsection{Findings and Comments on the Second Sub-Problem}

The questions asked in the interview form for the "Determination of the students of the music department of fine arts faculty regarding the Covid-19 distance education process", which is the second sub-problem of the research, are:

- Were you able to sufficiently interact and have dialogue with the instructor who taught in the distance education process? Why?

- What kind of contributions did the Covid-19 distance education make for you to improve yourself?

- Did the Covid-19 distance education process cause anxiety in you? If yes, explain.

Findings and comments regarding the data obtained from these questions are in Table 5.

Considering Table 5, it was seen that there was a negative response from four grades (9), due to internet connection problems for students' communication with the instructor in distance education courses. In addition, the $3^{\text {rd }}$ grades reported negative opinions about the communication problems arising from the limited time. Positive determinations, on the other hand, were the ones regarding the access to instructors outside the class hours, support with WhatsApp groups, and caring and instructive efforts.

S.4 (1) "Our communication with our teachers was very good. They made a great effort for us, both in our WhatsApp groups and in trainings. If I had not have experience connection interruptions, maybe it would have been more efficient for me."

S.1 (4) "Partially yes, there was no theoretical problem, but no matter how much the teacher explained in the applied courses, we could not reflect the techniques s/he showed to our instrument, due to the internet disruption."

In self-improvement theme, in addition to the negative codes (5) of lack of material and lack of not being able to work alone in applied courses, it was seen that the four grades (16) gave common answers in the positive category codes of being able to use time efficiently, to study regularly and to conduct research. In this case, it is concluded that students could improve themselves during the distance education process.

S.3 (1) "It did not contribute much. As we could not see the applied courses face-to-face, it was difficult to hear the sounds through the system and understand theoretically."

S.1 (2) "The support of my teachers and their being very interested in us in order for us not to feel purposeless in this process enabled me to improve myself, to see what I am lacking in reality and what my potential is."

S.3 (3) "I think that my researcher side has improved while doing the given homework."

S.3 (4) "I had the opportunity to work on courses or topics I did not understand in the past. I had the chance to spend more time on my instrument."

In the distance education process, negative codes for students' anxiety status (11) were generally determined as term extension due to falling behind the courses, uncertainty about exams, inexperience due to inability to know the system, inefficiency of working environments, and not being able to load homework due to connection problems. Despite this, 13 students stated that they continued the process without anxiety, and because they responded as "I did not worry" no code for the positive category could be produced.

S.1 (1) "I had the fear of falling behind the courses."

S.4 (2) "I thought that I could not pass the courses and extend one semester because I could not show the necessary attention to the courses. My anxiety was completely about the courses. "

\subsection{Findings and Comments on the Third Sub-Problem}

The questions asked in the interview form for the "Evaluations of the students of the music department of fine arts faculty regarding the Covid-19 distance education process", which is the third sub-problem of the research, are:

- What are your thoughts on the lack of attendance requirement in the distance education process?

- What are your thoughts on the student's active participation and communication in the distance education process?

- Do you think that the distance education process provides equal opportunities to every student? Why?

- As a student of music department, what are your thoughts in general if you compare your Covid-19 distance learning process with the distance education processes given in other departments?

Findings and comments regarding the data obtained from these questions are Table 6. 
Table-5. Students' views on the determinations related to the covid-19 distance education process.

\begin{tabular}{|c|c|c|c|}
\hline Grade & Themes & Category (Views) & Codes \\
\hline \multirow[t]{6}{*}{$1^{\text {st }}$ grade } & Communication with instructors & Negative (3) & $\begin{array}{l}\text { Internet connection } \\
\text { Caring } \\
\text { Teaching effort }\end{array}$ \\
\hline & \multirow{3}{*}{ Self-improvement } & Positive (3) & Whatsapp groups \\
\hline & & Negative (3) & $\begin{array}{l}\text { Applied courses } \\
\text { Laziness } \\
\text { Time }\end{array}$ \\
\hline & & Positive (3) & Studying comfortably \\
\hline & Anxiety status & Negative (4) & $\begin{array}{l}\text { Anxiety of falling behind } \\
\text { Inexperience } \\
\text { Fear of getting low marks } \\
\text { Unable to upload homework } \\
\text { Connection problems } \\
\text { Studying environment } \\
\end{array}$ \\
\hline & & Positive (2) & - \\
\hline \multirow[t]{10}{*}{$2^{\text {nd }}$ grade } & Interaction with instructor & Negative (1) & Internet connection \\
\hline & & \multirow[t]{3}{*}{ Positive (5) } & Communicating easily \\
\hline & & & Whatsapp groups \\
\hline & & & $\begin{array}{l}\text { Contacting outside academic } \\
\text { hours }\end{array}$ \\
\hline & \multirow[t]{3}{*}{ Self-improvement } & Negative (1) & Material deficiency \\
\hline & & & Time \\
\hline & & Positive (5) & $\begin{array}{l}\text { Adaptation to studying } \\
\text { Watching course records } \\
\text { Repeating more than one time }\end{array}$ \\
\hline & & Negative (2) & Anxiety of extending school \\
\hline & Anxiety status & & Exam \\
\hline & & Positive (4) & - \\
\hline \multirow[t]{9}{*}{$3^{\text {rd }}$ grade } & \multirow[t]{2}{*}{ Interaction with instructor } & \multirow[t]{2}{*}{ Negative (2) } & Internet connection \\
\hline & & & Limited time \\
\hline & & Positive (4) & $\begin{array}{l}\text { Communicating easily } \\
\text { Contacting outside academic } \\
\text { hours }\end{array}$ \\
\hline & Self-improvement & Negative (-) & \\
\hline & & Positive (6) & $\begin{array}{l}\text { Studying regularly } \\
\text { Researching } \\
\text { Obtaining new information }\end{array}$ \\
\hline & & Negative (3) & Inexperience \\
\hline & Anxiety status & & Anxiety of unable to understand \\
\hline & & & Absent students' being successful \\
\hline & & Positive (3) & - \\
\hline \multirow[t]{8}{*}{$4^{\text {th }}$ grade } & Interaction with instructor & Negative (3) & Internet connection \\
\hline & & Positive (3) & Communicating easily \\
\hline & Self-improvement & Negative (1) & Unable to study alone \\
\hline & & Positive (5) & $\begin{array}{l}\text { Repeating courses } \\
\text { Using time efficiently }\end{array}$ \\
\hline & & & Researching \\
\hline & \multirow[t]{3}{*}{ Anxiety status } & \multirow[t]{2}{*}{ Negative (2) } & Exam \\
\hline & & & Course process \\
\hline & & Positive (4) & - \\
\hline
\end{tabular}

Considering the data in Table 6 , it is seen that 16 students from 4 grades expressed their opinions in favor of the attendance requirement during the distance education process. When the codes for the attendance requirement are examined, it was determined that arbitrary and abusive situations arise in a comfortable environment and that the courses should be followed up regularly by all students and should be bound to rules and disciplines. On the other hand, 8 students stated that there should not be attendance requirement, and they expressed that there are students who do not have opportunities, there are connection problems, and they could compensate thanks to being able to watch the courses later even if they did not attend the course due to the insufficient facilities and connection problems. It was concluded from these findings that the majority of students wanted attendance requirement in distance education courses.

S.3 (1) "It is bad that there is no course attendance requirement, because some students act at their sweet will, attend the courses arbitrarily, while some students are constantly attending the classes and when we compare them, the students who attend the courses constantly and who do not arbitrarily should not be considered equal."

S.5 (2) "I wish there is attendance requirement because there is a purpose of this practice and education also has rules."

S.1 (3) "I found it reasonable to have no attendance requirement. There should not be attendance requirement because some students are not able to attend due to insufficient facilities, systemic errors, and so on." 
S.3 (4) "So, there was a reason for those who could not come, but there were a lot of people who exploited this in that way, so I think it was wrong."

While 7 students expressed with a common answer that they were able to communicate easily for active participation being high, 17 students stated that the active participation in the courses was low, and the reason for this was the connection problems and the low interest in the courses in distance education.

S.6 (3) "We had the option of raising hands in the "Zoom" application, but if we look at it in terms of active participation, people would turn off the camera and microphone and continue their work."

S.5 (4) "Distance education process enabled the students, who could not express themselves easily when they were face-toface, to express themselves easily, feel and participate actively in digital environment."

In the evaluation of whether distance education provides equal opportunities or not, 16 students made negative evaluations and stated that distance education does not provide equal opportunities due to lack of possibilities and materials. 7 people stated that it provided equal opportunities and the biggest factor was the fact that, with the common answer of the 4 grades, they were able to watch the courses later.

Table-6. Students' views on the evaluation of covid-19 distance education process.

\begin{tabular}{|c|c|c|c|}
\hline Grade & Themes & Category & Codes \\
\hline \multirow[t]{9}{*}{$1^{\text {st }}$ grade } & $\begin{array}{ll}\text { Class } & \text { attendance } \\
\text { requirement } & \end{array}$ & Should be (3) & \multirow{2}{*}{$\begin{array}{l}\text { Comfortable environment } \\
\text { Arbitrary behavior } \\
\text { Possibility gaps } \\
\text { Connection problems } \\
\text { Being able to watch later }\end{array}$} \\
\hline & & Should not be (3) & \\
\hline & Active participation & High & _- \\
\hline & & Low $(6)$ & $\begin{array}{l}\text { Lack of interest in courses } \\
\text { Connection problems }\end{array}$ \\
\hline & Equality of opportunity & Yes(1) & Being able to watch later \\
\hline & & No $(4)$ & Possibility gaps \\
\hline & Comparison & Positive & - \\
\hline & & Negative (3) & Inefficient for applied departments \\
\hline & & No idea $(3)$ & _- \\
\hline \multirow[t]{5}{*}{$2^{\text {nd }}$ grade } & $\begin{array}{ll}\text { Class } & \text { attendance } \\
\text { requirement } & \end{array}$ & Should be (4) & $\begin{array}{l}\text { Arbitrary behavior } \\
\text { Rule }\end{array}$ \\
\hline & & Should not be (2) & $\begin{array}{l}\text { Possibility gaps } \\
\text { Being able to watch later }\end{array}$ \\
\hline & Active participation & $\begin{array}{l}\operatorname{High}(2) \\
\operatorname{Low}(4)\end{array}$ & $\begin{array}{l}\text { Easy communication } \\
\text { Lack of interest in courses }\end{array}$ \\
\hline & Equality of opportunity & $\begin{array}{l}\text { Yes }(2) \\
\text { No }(4)\end{array}$ & $\begin{array}{l}\text { Being able to watch later Lack of } \\
\text { material }\end{array}$ \\
\hline & Comparison & $\begin{array}{l}\text { Positive (1) } \\
\text { Negative (5) }\end{array}$ & $\begin{array}{l}\text { Easy course process } \\
\text { Applied courses }\end{array}$ \\
\hline \multirow[t]{8}{*}{$3^{\text {rd }}$ grade } & $\begin{array}{l}\text { Class attendance } \\
\text { requirement }\end{array}$ & Should be (5) & $\begin{array}{l}\text { Exploitation } \\
\text { Regular follow-up }\end{array}$ \\
\hline & & Should not be (1) & Inadequate possibilities \\
\hline & Active participation & High (3) & Easy communication \\
\hline & & Low (3) & $\begin{array}{l}\text { Lack of interest } \\
\text { Connection problems }\end{array}$ \\
\hline & Equality of opportunity & Yes (3) & Being able to watch later \\
\hline & & No $(3)$ & Possibility gaps \\
\hline & Comparison & Positive (1) & $\begin{array}{l}\text { Teaching a lesson in a fun way } \\
\text { Inadequate possibilities }\end{array}$ \\
\hline & & Negative (5) & Applied courses \\
\hline \multirow[t]{8}{*}{$4^{\text {th }}$ grade } & $\begin{array}{ll}\text { Class } & \text { attendance } \\
\text { requirement } & \end{array}$ & Should be (4) & $\begin{array}{l}\text { Discipline } \\
\text { Laziness } \\
\text { Negative effect }\end{array}$ \\
\hline & & Should not be (2) & $\begin{array}{l}\text { Possibility gaps } \\
\text { Connection problems } \\
\text { Being able to watch later }\end{array}$ \\
\hline & Active participation & High (2) & $\begin{array}{l}\text { Easy communication } \\
\text { Feeling comfortable }\end{array}$ \\
\hline & & Low $(4)$ & $\begin{array}{l}\text { Lack of interest in courses } \\
\text { Communication problems }\end{array}$ \\
\hline & Equality of opportunity & Yes (1) & Being able to watch later \\
\hline & & No $(5)$ & $\begin{array}{l}\text { Readiness } \\
\text { Possibility gaps }\end{array}$ \\
\hline & Comparison & Positive (1) & One-to-one education possibility \\
\hline & & Negative (5) & Applied courses \\
\hline
\end{tabular}

S.2 (1) "No I don't think so. The reason is that not everyone has a strong internet connection or sometimes even an internet connection. Because of this, I think that not everyone was given equal training." later."

S.5 (3) "It gave every student equal opportunity because if we did not understand in the course, we could watch the records

In the comparison of other departments for distance education courses, 3 students responded positively and stated that they were given a more comfortable, fun and one-to-one training opportunity. 18 students made 
negative evaluations and stated that the distance education process was inefficient for applied courses, and 3 students stated that they had no idea.

S.6 (3) "Since our courses are mostly applied, they are not very efficient in distance education, but in other departments, they are able to overcome this pandemic period with the least harm since verbal courses are intense."

S.1 (4) "Since the education in music department is based on sounds and auditory senses, there is a problem of perception in the subjects that the teacher wants to explain, due to the connection problems in distance education. I think that distance education is insufficient in applied courses since we have more applied courses than other departments."

\subsection{Findings and Comments on the Fourth Sub-Problem}

The questions asked in the interview form for the "Recommendations of the students of the music department of fine arts faculty regarding the Covid-19 distance education process", which is the fourth sub-problem of the research, are:

- What are your recommendations about the practical courses given in the Covid-19 distance education process in FAF Music departments?

- What are your recommendations regarding the theoretical courses given in the Covid-19 distance education process in FAF Music departments?

- What are your general recommendations regarding the Covid-19 distance education process?

- -Do you think that distant education should continue in the next academic years, why?

- In the case of the continuation of the process for the next education and training periods, which courses would you like to continue with distance education and which courses would you want to continue with face-to-face education, why?

Findings and comments regarding the data obtained from these questions are as follows:

Table-7. Students' recommentadions on the Covid-19 distance education process.

\begin{tabular}{|c|c|c|}
\hline Grade & Themes & Codes \\
\hline \multirow{12}{*}{$1^{\text {st }}$ grade } & \multirow{5}{*}{ Applied courses } & New software (2) \\
\hline & & Solving technical problems $(5)$ \\
\hline & & Prolonging course hour (3) \\
\hline & & Course in little groups (1) \\
\hline & & Being given no homework (2) \\
\hline & \multirow{3}{*}{ Theoretical courses } & Live courses (3) \\
\hline & & Uploading video (2) \\
\hline & & Prolonging course hour (4) \\
\hline & \multirow{4}{*}{ General } & Prolonging course hour (4) \\
\hline & & Face-to-face applied course (5) \\
\hline & & Fixing system errors $(2)$ \\
\hline & & No applied exams (2) \\
\hline \multirow{9}{*}{$2^{\text {nd }}$ grade } & \multirow{3}{*}{ Applied courses } & Attendance requirement (3) \\
\hline & & Prolonging course hour (4) \\
\hline & & Face-to-face education (5) \\
\hline & \multirow{3}{*}{ Theoretical courses } & Live courses $(4)$ \\
\hline & & Video uploading (2) \\
\hline & & Fixing system errors 4 ) \\
\hline & \multirow{7}{*}{ Applied courses } & Attendance requirement (4) \\
\hline & & Continuation of distance education (1) \\
\hline & & Face-to-face applied courses (5) \\
\hline \multirow{12}{*}{$3^{\text {rd }}$ grade } & & Prolonging course hour $(4)$ \\
\hline & & One-to-one course $(2)$ \\
\hline & & Face-to-face education (5) \\
\hline & & Solving technical problems (3) \\
\hline & \multirow{3}{*}{ Theoretical courses } & Live courses $(3)$ \\
\hline & & Face-to-face education (1) \\
\hline & & Less homework (2) \\
\hline & \multirow{9}{*}{ Applied courses } & Attendance requirement (3) \\
\hline & & Face-to-face education in applied courses (5) \\
\hline & & Less homework (3) \\
\hline & & Continuation of the process (1) \\
\hline & & No exams (3) \\
\hline \multirow{12}{*}{$4^{\text {th }}$ grade } & & Attendance requirement (3) \\
\hline & & Uploading video records (1) \\
\hline & & Homework dominated course process (1) \\
\hline & & Solving connection problems (5) \\
\hline & \multirow{2}{*}{ Theoretical courses } & Less course content (2) \\
\hline & & Solving connection problems (5) \\
\hline & \multirow{6}{*}{ General } & Attendance requirement (3) \\
\hline & & Face-to-face applied course (5) \\
\hline & & Additional courses (1) \\
\hline & & Providing opportunity to each student (2) \\
\hline & & Solving connection problems (3) \\
\hline & & Less course content $(2)$ \\
\hline
\end{tabular}

Considering the recommendations of the students for the applied courses in the distance education process in Table 7, it is seen that they make recommendations about the solution of the technical and connection problems 
(13), extension of the class hours (11), conduction of this course with face-to-face education (10), attendance requirement (6), courses in small groups or one-to-one (3), no homework (2), and developing a new program for applied courses (2).

S.6 (1) "Fixing the connection problems and technical problems or developing new software."

S.2 (3) "It would be better for students to take the course individually or in small groups for applied courses."

Looking at the theoretical courses, it was seen that the students advised that the courses be done live (10). Also, they expressed their opinions regarding the fixing of connection problems (5) and system errors (4), video recitation (4), extension of course hours (4), lesser course content (2) and less homework (2).

S.2 (2) "My advice on this issue is to fix some system errors of the application."

S.6 (4) "Subjects may not be as intense as in face-to-face education. A more in-depth course model over a more restricted subject can be developed."

The general recommendations of students regarding the distance education process are that applied courses should be held dominantly face-to-face (20). This is followed by the recommendations of attendance requirement (10), no exams (5), less homework (3), fixing connection problems (3) and system errors (2), reduction of the course content (2), and equal opportunity for each student (2). As a result, it was concluded that applied courses should be given with face-to-face education in general recommendations of students about distance education.

S.3 (1) "It is better not to make exams since we have problems in applied courses."

S.6 (2) "There must be attendance requirement."

S.5 (3) "Less homework."

S.2 (4) "The implementation of distance education in our department is a very troublesome process and applied courses should be held face-to-face."

Table-8. Students' views on the continuation the distance education process.

\begin{tabular}{c|c|c}
\hline Grade & Options & No \\
\hline & Yes & 5 \\
\hline $1^{\text {st }}$ grade & 1 & 4 \\
\hline $2^{\text {nd }}$ grade & 2 & 6 \\
\hline $3^{\text {rd }}$ grade & - & 6 \\
\hline $4^{\text {th }}$ grade & - & 21 \\
\hline Total & 3 & \\
\hline
\end{tabular}

In Table 8 , only 3 students from $1^{\text {st }}$ and $2^{\text {nd }}$ grades stated that the distance education should continue in the further process, in their responses to whether distance education should continue or not. 21 students expressed their opinions in favor of the discontinuation of distance education.

Table-9. Students' views on the courses they want to continue in the covid-19 distance education process.

\begin{tabular}{|c|c|c|c|c|}
\hline Grade & Options & & & \\
\hline & Theoretical courses & Applied courses & All & None \\
\hline $1^{\text {st }}$ grade & 2 & 1 & 2 & 1 \\
\hline $2^{\text {nd }}$ grade & 4 & - & 1 & 1 \\
\hline $3^{\text {rd }}$ grade & 3 & - & - & 3 \\
\hline $4^{\text {th }}$ grade & 4 & - & - & 2 \\
\hline Total & 13 & 1 & 3 & 7 \\
\hline
\end{tabular}

In Table 9, when the students' answers, regarding the courses they would want to continue if distance education process continues, are examined, it is concluded that 12 students want theoretical courses, 3 students want all courses and only 1 student wants applied courses via distance education. In addition, 4 students stated that no courses should be conducted with distance education and they should continue with face-to-face education. Considering these results, it can be said that distance education is incomplete or insufficient in terms of applied courses and students do not want to take applied courses with distance education.

\section{Results, Discussion and Recommendations}

According to the results obtained from the opinions regarding the problems faced by the students of Fine Arts faculties during the Covid-19 distance education process, which is the first sub-problem of the research.

While most of the students (21) gave negative opinions for applied courses, only 2 stated that the process was smooth for them. From the student views for applied courses, problems such as the internet connection, inadequate work environment, inefficiency in courses due to student's lack of material and not being able to adapt to the distance education system were identified. Regarding the theoretical courses, 11 students give negative opinions while 13 students have positive opinions. According to the opinions of the students, the problems they faced in theoretical courses during the distance education process were determined as the internet connection problems, lack of interest and attention to the courses by the students, more homework than before, not understanding the courses and not communicating with the instructors.

In parallel with this study, Keskin and Ozer (2020) in their study in which they evaluated students' feedback on web-based distance education in the Covid-19 process, saw that web-based distance education contributed much more to the theoretical knowledge level of students when compared to practice skills, and they concluded that they could not communicate with the instructors easily (49.9\%), and they had opinions that there were technical problems (53.9) during the training.

Again, with similar results, Altuntas (2020) stated in her study, in which she investigated the attitudes of the students about the status of distance education applied in the Covid-19 process, that in the distance education process, for $12.5 \%$ of the students it was productive for applied courses and for $87.5 \%$ it was inefficient; for theoretical courses, $21.5 \%$ thought it was processed efficiently and for $78.5 \%$ of them it was inefficient. Based on all 
these findings, it can be said that Web-Based Distance Education is not as efficient as the face-to-face education process for the departments where the applied courses are predominant.

In the theme of "interaction with the instructor" regarding the second sub-problem of the research, 9 students expressed negative opinions and stated that this was poor communication due to internet disconnections and limited time. In accordance with the positive opinions of the 15 students, it was concluded that they could communicate with the instructors outside of the classroom through applications such as Whatsapp, and the instructors supported and tried to teach by supporting the students.

In her research, Altuntas (2020) stated with parallel findings that the uncertainty experienced by the students in the face of the education method they encountered for the first time can only be resolved with the follow-up and informing of the instructors, and in this sense, it is extremely important for the students to communicate with the instructors and solve their problems if necessary, and the majority of the participant students (\% 61) interacted with the instructors via text message and e-mail.

In the theme of "self-improvement", 5 students stated that they could not improve themselves in individual courses, such as instruments, and that the distance education process increased their laziness levels because they were not able to work efficiently alone and could not get efficiency from applied courses. The study of Cheng and Chau (2016) emphasized the important role of social interaction in web-based education and reported that lack of social bonds and low solidarity among students in web-based education may decrease students' social interactions and may have low performance and high exhaustion rate. From the codes in the positive category (19), it was concluded that students can use their time efficiently and work comfortably, acquire new information through regular study and research, and improve themselves by watching the courses again. Keskin and Ozer (2020) similar to these studies, reported that web-based distance education allows $38.7 \%$ of students to receive information at the specified time, $38.5 \%$ of them to learn at their own learning speed, but it reduces social interaction and team work for $36 \%$ of them.

In the case of anxiety, which is the third theme, 11 students stated that they experienced various concerns during the distance education process, and when the codes related to these anxiety situations were examined, the results were low notes and fear of extending the term, inability to upload homework due to connection problems and systemic errors, and the inexpertness related to using the distance education system for the first time, anxiety related to the functioning of the course process and the way exams were conducted.

Although distance education has positive aspects in many ways, it has some limitations in terms of implementation and providing learning. These limitations can be listed as the student's not being able to socialize like in the school environment, that the courses requiring practice cannot be provided with distance education platforms, the low interest and motivation in the courses due to the low level of face-to-face education, and the difficulties students face in using the technological devices (Agir, 2007).

In the theme of "attendance requirement" regarding the third sub-problem of the research, 16 students stated that there should be attendance requirement, and added that they can be more comfortable to attend courses at home, that the students might abuse this process by attending the courses arbitrarily, and that the process should proceed with rules and discipline by following the courses regularly. When the codes obtained from the opinions of the students stating that there should not be attendance requirement are examined, it was concluded that the course process is disrupted due to connection problems, as the courses are registered in the system, although they do not participate in the course, they can watch and compensate later, and since each student does not have equal opportunities, s/he cannot follow the distance education course period regularly and therefore, there should be no attendance requirement.

In the research of Durak, Cankaya, and Izmirli (2020) it was concluded that during the Covid-19 distance education process, the attendance status of the students was followed in approximately half of the universities, but some of the students did not have a computer and had internet connection problems, and therefore it is not appropriate for such students to follow the attendance status especially in live courses, which may cause them to fail. In this case, it would be appropriate for the universities to decide on the attendance requirement after determining the facilitations of the students and making the necessary improvements.

In the theme of "Active Participation", 17 students stated that there was not much active participation in the courses, they had communication difficulties due to connection problems and students were less interested in the courses during the distance education process. 7 students, on the other hand, expressed their opinion that active participation was higher than the normal process because they felt comfortable by communicating with the instructors.

The answers, Keskin and Ozer (2020) obtained in their studies for the open-ended questions "By improving the Internet infrastructure, students can take a more active role and participate in courses verbally," and "Student participation can be realized, and thus, the education provided will be more efficient," are in line with the findings of this study.

Considering the codes of the students' opinions about whether distance education provides equal opportunities in education or not, with positive opinions and similar answers of a total of 7 students from 4 grades, it is concluded that everyone has equal opportunities in terms of following the course records and this creates an equal opportunity in education. 16 students, on the other hand, stated that the process does not provide equal education opportunities to all, students do not have equal financial and technological opportunities, and everyone is not equal in distance education in terms of readiness.

When the data obtained from comparing the distance education process with other departments of the music department students, it is seen that 18 students gave negative opinions about the comparison, only 3 students responded in a positive category and 3 students did not have an opinion about the distance education process given in other departments. In the negative category, as a common opinion of all four grades, it was concluded that the distance education system is inefficient in terms of applied courses in the music department. The students who gave positive opinions expressed that the distance education process in the music department is more comfortable, fun and more efficient in terms of providing one-to-one courses than other departments. 
Keskin and Ozer (2020) in their study with 652 undergraduate students, concluded that the contribution of web-based distance education to students' theoretical knowledge level is more than their contribution to the practice skill. They stated that this result shows that students need more face-to-face education especially in applied units, and performing one-to-one practice after listening could contribute more to professional practice skills (Keskin \& Ozer, 2020).

When the recommendations of the students of the music department regarding the distance education process are examined, which is the fourth sub-problem of the study, the findings were like: the technical and connection problems for the applied courses should be solved (13), class hours should be extended (11), there should be attendance requirement (6), the applied courses should continue in face-to-face education, not in distance education (5), the courses should be conducted in small groups or as one-to-one (3), a new software program for applied courses should be developed (2), and there should be no homework in applied courses (2).

From the students' views on the theoretical courses, these were concluded: to make the courses live (10), to solve the problems related to connection and system (9), to include video narratives in the courses (4), to reduce the content of the courses (2) and homework (2).

When looking at the codes related to the general recommendations of the students regarding the Covid-19 distance education process, it was concluded that the view that the applied courses should continue with face-toface education (20) is dominant. Again, the view arguing that there should be attendance requirement (10) is intense, and it is followed by other recommendations: there should not be applied exams (5), technical and connection problems should be solved (5), course hours should be extended (4), there should be less homework (2) and course content (2), and every student should be provided with equal opportunities (2).

In the Music Departments of the Faculty of Fine Arts where individual courses are held intensely, individual instrument courses are of great importance. It was concluded in line with the opinions of the students that some applied courses such as individual instrument courses given by distance education are not as effective as face-to-face education in the music departments. As a matter of fact, Can and Yungul (2017) in their studies with graduate students, concluded that students support traditional education on the effectiveness of the instrument course program. While performing the target behaviors that are planned to be gained by the students in instrument education, it may be necessary to respond to the student physically or establish visual or auditory communication in order to explain the stance, attitude or some technical issues of the instrument from time to time.

Again, according to the student's opinion about whether they want the continuation of the distance education process, which is one of the results of the research, only 21 students stated that the process should continue with distance education. In addition, in case of the continuation of distance education, it was concluded that the students mainly had the opinion that the theoretical courses (12) should continue with the distance education. This was followed by the opinions that no courses should be done with distance education (4), and all courses should be done with distance education (3).

According to the study of Zirhlioglu (2006) the information received in formal education is more permanent and there is a difference between formal education and distance education in terms of learning. In the study of Altuntas (2020) in which the findings were parallel to this research, the students were asked which education system they would prefer when the conditions were suitable after the pandemic process was completed, and $90.3 \%$ of them wanted to continue their education with formal education and $9.7 \%$ with distance education. In addition, when the efficiency of practical and theoretical courses with distance education method was questioned in the pandemic process, $12.5 \%$ of the students responded that it was processed efficiently and $87.5 \%$ inefficiently for applied courses; $21.5 \%$ thought it was processed efficiently and $78.5 \%$ inefficiently for theoretical courses. In the study of Keskin and Ozer (2020) with similar results, it was concluded that $84.4 \%$ of students thought that webbased distance education is not as effective as face-to-face education, $45.7 \%$ of them thought that it is an alternative to face-to-face education, and also, the contribution of distance education to theoretical courses and general culture is moderate and found to be relatively higher than professional practice skills. Face-to-face sessions in the classroom continue to be valued by students (Richardson, Maeda, Lv, \& Caskurlu, 2017).

In the light of these results, it can be suggested that students need more face-to-face education in applied units such as music departments of fine arts faculties. Having students practice one-to-one after listening to the course content can contribute to the student's professional practice skills. It is thought that it is important to develop distance education especially for applied courses or to find alternative methods (Altuntas, 2020; Keskin \& Ozer, 2020).

Improvement and infrastructure studies for the internet connections and technical problems, which are the main problems experienced by the students of the Music Department, should be accelerated, and more technical support should be provided for the applied departments.

While the distance education process is continuing in the applied departments of the universities, it is important to eliminate the problems that occur during the process without losing time and interrupting the education by conducting studies that would take feedback aiming the opinions of students and instructors.

Again, in the process, if students are provided with continuous support, participation in the distance education process can be increased. Also, in-service trainings on distance education can be given to instructors.

More effective and appropriate software/programs that can be used in the distance education process for music departments can be produced and developed. Thus, the distance education process can be made more efficient and more active by minimizing the problems students experience with music courses in the process.

In crisis situations such as pandemics where distance education is compulsory, the state and universities should provide the necessary support to the students who are financially and technologically impaired and provide each student equal education in order for them to have equal educational opportunities.

As a result of the urgent and rapid transition to distance education in the pandemic process, it is recommended to carry out studies in music departments and other applied departments in order to improve the quality of the service and education in the future by improving the existing system. 


\section{References}

Adileh, M. T. (2012). Teaching music as a university elective course through E-learning. Australian Journal of Music Education, 1, 71 -79.

Agır, F. (2007). Determining the teachers' attitudes towards distance education in public primary school and private primary school. Unpublished Master Thesis. Balıkesir University Institute of Science Department of Computer Education and Instructional Technology, Balıkesir.

Altun, D., Telli, \& Yamamoto, G. (2020). Coronavirus and the rising of online education. Journal of University Research, 3(1), 25-34. Available at: https://doi.org/10.32329/uad.711110.

Altuntas, Y. N. (2020). Investigation of students' attitudes towards applied distance education in the COVID-19 pandemic process in higher education institutions: Example of physiotheraphy and rehabilitation department. Necmettin Erbakan University Faculty of Health Sciences Journal, 3(1), 15-20.

Buyukozturk, S., Cakmak, E. K., Akgun, O. E., Karadeniz, S., \& Demirel, S. (2010). Scientific research methods. Ankara: Pegem A. Press.

Can, A. A., \& Yungul, O. (2017). Determining the views of graduate students, who receive instrument education at music institute, towards distance education. The Journal of Academic Social Science, 5(45), 155-168.

Cheng, G., \& Chau, J. (2016). Exploring the relationships between learning styles, online participation, learning achievement and course satisfaction: An empirical study of a blended learning course. British Journal of Educational Technology, 47(2), 257-278. Available at: https://doi.org/10.1111/bjet.12243.

Daubney, A., \& Fautley, M. (2020). Editorial research: Music education in a time of pandemic. British Journal of Music Education, 37(2), 107114. Available at: https://doi.org/10.1017/s0265051720000133.

Durak, G., Cankaya, S., \& Izmirli, S. (2020). Examining the Turkish universities' distance education systems during the COVID-19 pandemic. Necatibey Faculty of Education Electronic Journal of Science and Mathematics Education, 14(1), 787-809. Available at: 10.17522 /balikesirnef. 743080 .

Ekiz, D. (2003). Introduction to research methods and methods in education (1st ed.). Ankara: Anı Press.

Esen, A., Oral, G., \& Yalcinkaya, M. (2014). A qualitative research about mobbinng implications in educational institutions. Sakarya University Journal of Education, 4(1), 62-80.

Karahan, A. S. (2016). The evaluation of synchronic distance piano teaching in comprasion with the traditional piano teaching. International Periodical for the Languages, Literature and History of Turkish or Turkic, Turkish Studies, 11(21), 211-228. Available at: https://doi.org/10.7827/TurkishStudies.11244.

Karip, E. (2020). COVID-19: School closures and aftermath. Retrieved from https://tedmem.org/vurus/covid-19-okullarin-kapatilmasi-vesonrasi. [Accessed 12/06/2020].

Keskin, M., \& Ozer, K. D. (2020). Evaluation of studenst' feedbacks on web-based distance education in the COVID-19 process. Izmir Kattp Celebi University Faculty of Health Sciences Journal, 5(2), 59-67.

Kose, E. (2013). Scientific researsch models. In Kincal, R. (Ed.), Scientific Research Methods. Ankara: Nobel Akademik Press.

Merriam, S. B. (2009). Qualitative research: A guide to design and implementation: Revised and expanded from qualitative research and case study applications in education. San Franscisco, USA: Jossey-Bass.

Miles, M. B., \& Huberman, A. M. (1994). Qualitative data analysis: An expanded sourcebook. New York: Sage Publications, Inc

Miles., M. B., \& Huberman, A. M. (2016). An extended resource book: Qualitative data analysis (S. Akbaba-Altun $\Xi^{\circ}$ A. Ersoy, Trans. Ed.). Ankara: Pegem Academy.

Okan, S. (2017). The effect of distance teaching model on violin learning. Unpublished Doctoral Dissertation. Inonu University Institute of Education Sciences, Malatya.

Richardson, J. C., Maeda, Y., Lv, J., \& Caskurlu, S. (2017). Social presence in relation to students' satisfaction and learning in the online environment: A meta-analysis. Computers in Human Behavior, 71, 402-417. Available at: https://doi:10.1016/j.chb.2017.02.001.

Turnuklu, A. (2000). A qualitative research teahnique that can be used effectively in pedagogical research: Interview. Educational Administration: Theory and Practice, 6(4), 543-559.

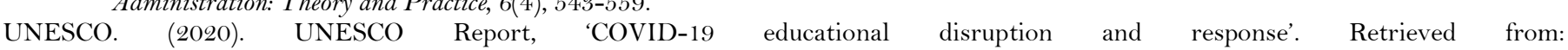
https://en.unesco.org/covid19/educationresponse.

Wang, W., Zhang, D., \& Du, R. (2020). Original: Remdesivir in adults with severe COVID-19: A randomised, double-blind, placebo.

Yildirim, A., \& Simsek, H. (2006). Qualitative research methods in the social sciences (6th ed.). Ankara: Seçkin Press.

YOK. (2020a). Statement on distance education to be applied at universities. Retrieved from: https://www.yok.gov.tr/Sayfalar/Haberler/2020/universitelerdeuygulanacak-uzaktanegitime-iliskin-aciklama.aspx. [Accessed 10.06.2020].

Yungul, O. (2018). Web based distance learning in music education. International Journal of Literature Culture Education, 7(2), 1333-1348.

Zhong, R. (2020). The coronavirus exposes education's digital divide. Retrieved from The New York Times: https://www.nytimes.com/2020/05/14/technology/china-schools-coronavirus.html.

Zirhlioglu, C. (2006). Statistical analysis of computer usage and distance learning in Turkey and between the regions of Turkey. Unpublished Master Thesis, Marmara University Institute of Science, Istanbul. 